\title{
From Quanzhou, China to Oxford, UK: An account of the Selden Map of China and its conservation
}

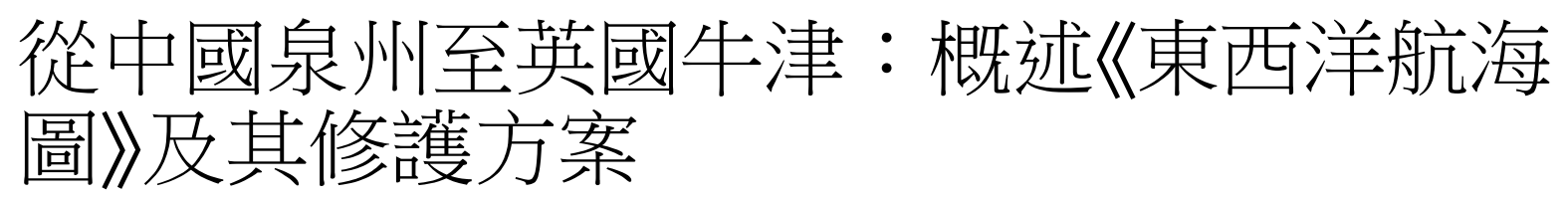

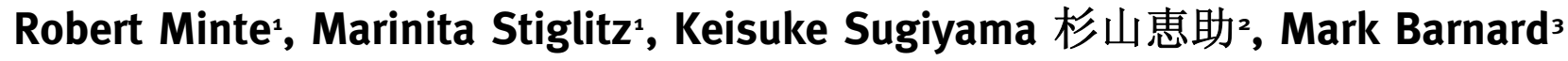 \\ 'Conservation and Collection Care, Bodleian Library, University of Oxford, UK, ${ }^{2}$ Hirayama Studio, Department of Conservation and Scientific Research, The British Museum, London, UK, ${ }^{3}$ Conservator in Private Practice, London, UK \\ '英國牛津大學博多利安圖書館藏品修復及保護組 ${ }^{2}$ 英國倫敦大英博物館 文物保護和科學研究部 平山郁夫東 方書畫修復室}

Keywords: Chinese map, Collaboration, Conservation, Previous restoration, Ming dynasty

關鍵詞：東西洋航海圖、合作、修護、早前的修復、明代

The rediscovery in 2008 of 'The Selden Map of China' at the Bodleian Library, University of Oxford, Oxford, UK, has greatly expanded knowledge of early seventeenth-century sea trade in East Asia [1], and generated a new collaboration between conservators at the Bodleian, British Museum, and British Library, with the aim of assessing the map's condition and its long-term preservation. The collaboration was instrumental in establishing a conservation treatment bringing together traditional Far Eastern painting conservation and Western paper conservation techniques to stabilise the map and allow it to be fully appreciated in the context of a Western collection.

The map, measuring $1.6 \times 1 \mathrm{~m}^{2}$, painted with carbon ink and watercolours on Chinese paper, is a unique example of Chinese merchant cartography, depicting a network of shipping routes, starting from the port of Quanzhou, Fujian province, and reaching Japan and Indonesia. These unusual shipping routes are accompanied by a rich depiction of the landscape with rivers, mountains, and plants, making this map a beautiful visual artefact.

The map, thought to date from the 1620 s, arrived at the Bodleian in 1659, following the bequest of the London jurist and Orientalist John Selden, enriching one of the earliest collections of Chinese material in England at the time. The map's Mandarin text was annotated in Latin in 1687 by Thomas Hyde, the

Correspondence to: Marinita Stiglitz, Conservation and Collection Care, Bodleian Library, University of Oxford, Oxford OX1 3BG, UK. Email: marinita.stiglitz@bodleian.ox.ac.uk
2008年，《東西洋航海圖》在英國牛津大學的博多利 安圖書館重新出現, 不但大大擴闊了人們對十七世 紀初期東亞地區海上貿易的認識 [1], 更促成了博多 利安圖書館、大英博物館與大英圖書館這三大機構 的修復人員展開一項新的合作項目, 共同評估航海 圖的現況, 從而嶅定長遠的保存方案。這個合作項 目有助建立一個揉合傳統遠東書畫與西方紙本修護 技巧的修復處理方案, 以穩定航海圖的狀況, 讓它 可以充分發揮其作為一件西方館藏的研究和觀賞價 值。

航海圖長1.6米、寛1 米, 以碳墨及水彩在中國紙 上繪製, 是中國商船航海圖的獨特例子, 所繪畫的 航海路線網絡由福建省泉州港開始, 遠及日本與印 尼。除了這些不常見的航線外, 航海圖還載有詳盡 的地貌景致, 包括河川、山巒、植物等, 絕對是一 件精美的藝術品。

航海圖估計繪於1620年代, 於1659年隨着倫敦法 律學及東方學家約翰 - 雪爾登去世後的捐贈, 成為 博多利安圖書館的藏品, 豐富了當時英國其中一個 最早的中國文物館。1687年, 博多利安圖書館館長 湯瑪斯 - 海德在耶穌會教士沈福宗的協助下, 把航 海圖上的漢文加上拉丁文註釋。沈福宗於1686年從 南京到訪英國詹姆士二世皇宮，他是英國文獻紀錄 上出現的首位中國人, 也是博多利安圖書館中首位

聯繫人: Marinita Stiglitz, Conservation and Collection Care, Bodleian Library, University of Oxford, Oxford OX1 3BG, UK 電郵：marinita.stiglitz@bodleian.ox.ac.uk 
then Bodleian Librarian, with the help of Michael Shen Fuzong, a Jesuit convert visiting from Nanking who had arrived in 1686 at the court of James II. He was the first recorded Chinese person in Britain and the first to catalogue the Chinese collection in the Bodleian Library, revealing what the collection contained and which way up to hold Chinese books.

The map was frequently displayed for its unusual character and beauty, so much so that by the early twentieth century it had deteriorated and had been repaired and mounted as a wall hanging [2]. Already by the 1970s the map presented significant damage, as conservation records testify. Ethical considerations about the map's original material characteristics and its later patches and mountings underpinned the conservation treatment. The paper support was made of three thin Chinese sheets of paper joined together with a narrow overlap prior to painting, each sheet being double layered. The 1919 mounting consisted of a thick paper border, a cloth lining, and a wooden stave at the top edge; the rod at the bottom edge was missing. The border held fragments of an earlier paper border, with some of the 1687 Latin annotations, recognised as important evidence of an early mounting of the map. With transmitted light it was possible to see that under the lining the paper support was reinforced with a few large patches, surrounded by many smaller ones. After observing these material aspects, a preliminary chronology of the map's production, repairs, and formats was traced to inform the conservation treatment.

The inflexible mounting, tightly rolled format, and patches had caused severe distortions and cracking of the primary support, making the map too unsafe for consultation and display; whenever the map was unrolled it would lose fragments and its cracks would deepen (Fig. 1). Having a full understanding of the map's construction and materials, various treatment options were explored. The removal of the lining and patches was considered essential to adequately address the damage and Far Eastern painting conservation techniques were used to enable controlled humidification of an item with its paper support in an extremely fragmentary state and a rich, but overall stable, paint layer.

Firstly a long humidification method, consisting of the repeated application of layers of rayon paper (Yoshida Co., Ltd, Kyoto, Japan) with brush and water allowed the map to relax while supporting it, swelling the adhesive holding the lining. As a result the lining was slowly peeled off by hand in three large sections.

Secondly, the 'dry' backing removal method was adopted $[3,4]$. The map was stabilised with a temporary facing of light-weight rayon paper adhered onto the recto with funori adhesive (Japanese seaweed,
編纂中文書籍目錄的學者, 記錄了藏書的內容、正 確閱讀中文書籍和持書的方法。

由於航海圖美觀而且罕有, 常作展覽之用, 因此 到了二十世紀初已出現劣化情況, 曾被修補及裝裱 成掛牆畫 [2]。修護紀錄顯示, 航海圖到了1970年代 已出現嚴重損壞。修復方案是根據航海圖原有物料 的特性、後期的修復補丁以及裝裱形式的專業操守 考量來制定。航海圖本身的紙張在繪製前是以三張 雙層的薄中國紙黍接而成, 在併接處兩張紙的緣邊 重疊。而於1919年進行的裝褤則加了厚紙裱邊、棉 布背托和天杆小木棍, 卻沒有地杆。航海圖邊還保 留了早期紙裱邊的碎片，部份碎片上有1687年的拉 丁文註釋, 是反映它早前進行裝裱的重要證據。在 透射光下可看到航海圖背面視布下的紙張曾以數大 片補丁加固, 周邊還有較細小的補丁。透過觀察這 些物料的特性, 我們已能初步追溯出航海圖製作、 修復和裝裱形式的年代, 為修復方案提供依據。

由於裝裱欠缺柔韌、航海圖緊繃繃地卷着, 又有 多處補丁, 導致航海圖嚴重變形和開裂, 狀況惡 劣, 已不適宜檢閱及展出。每當開展航海圖時, 均 有碎片掉落, 開裂情況愈趨加劇（圖1）。透徹地認 識航海圖的結構與物料後, 我們得出了多種可行的 修護處理方法。首先必須移除舊有的托裱與補丁, 以減輕它的損壞情況, 也採用了遠東書畫的修復技 巧, 為這幅極為脆弱易碎, 但色彩豐富、顏料層大 致穩定的航海圖進行受控性潤濕。

我們先採用長時間加濕的方法, 在航海圖背面舖 上多層人造絲紙 (日本京都Yoshida Co., Ltd.生 產）, 然後以毛掃把水掃在絲紙表面, 讓航海圖紙 張在承托下緩緩放鬆, 同時令秥合背禂的黏合劑膨 脹, 這個步驟重複多次後, 再小心用人手把䘽布分 三大部份揭去。

接下來我們使用「乾燥」式的揭裱方法 $[3,4]$, 把 一層輕薄的人造絲紙以布海苔 (日本海藻, 購於日

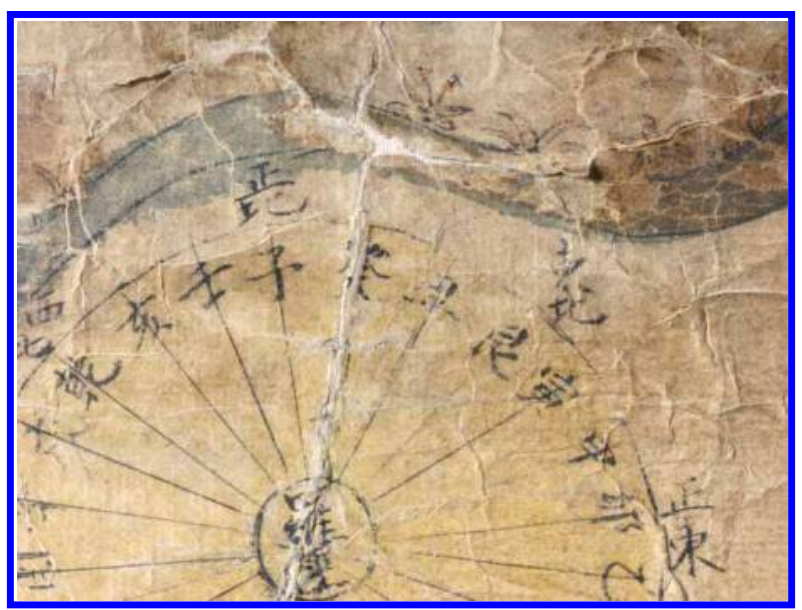

Figure 1 Detail before conservation

圖 1 修復前的航海圖細節 
available from Yoshida Co., Ltd). It was then dried flat with false margins of Japanese sekishu paper (Masumi Corporation, Tokyo, Japan) on a karibari drying board before being secured with the same margins onto a polymethyl methacrylate board, with the verso exposed. The patches, thick paper border, and adhesive residues were locally and slowly humidified by brush or through a Sympatex ${ }^{\circledR}$ membrane (a synthetic moisturepermeable material, available from http://www.conser vation-by-design.co.uk), and removed using scalpels, bamboo spatulas, and tweezers. The earlier border with the seventeenth-century annotations was preserved in place, and losses were infilled with xuan paper (Anhui Paper Factory, Anhui, China), toned to the map's background colour. This method enabled the dimensional stability of the paper support to be maintained while applying a minimum amount of moisture only where required, working over many months.

Three layers of light-weight Japanese usumino paper (Hasegawa Washi Kobo, Mino-city, Japan) were applied with wheat starch paste, supporting the map with a flexible lining and preserving the characteristics and appearance of a scroll. Finally, considering its long-term preservation, it was decided to store the map flat, mounted with Japanese paper hinges along its four edges on a light-weight honeycomb panel (Fig. 2).

During conservation, the removal of the lining allowed a close inspection of the verso of the map. It revealed overlapping patches of various types of paper and a surface layer of adhesive which presented in certain areas the imprint of the 1919 cloth lining's pattern and in others a coarser pattern or both. This indicated not only that the map had a lining previous to the twentieth century, but also that the patches were applied at two separate times before and after this earlier lining. Additionally fragments of cloth were found, offering concrete evidence of this earlier lining. These observations enriched the map's preliminary chronology of restorations and formats.

The exposed verso also revealed remarkable evidence of previously unknown mapmaking techniques. A drawing of the main shipping routes was found hidden on the verso of the map, matching that seen on the recto, unexpectedly making clear that the map was drawn starting with the network of trading routes precisely marked with compass bearings. This advanced the academic debate about how the map was constructed, and its provenance.

Material components of the primary support, patches, cloth lining, and paint layer were identified with analytical techniques (polarised light microscopy, Raman spectroscopy, X-ray fluorescence, and Fourier transform infrared spectroscopy) contributing to our understanding of the map's production.

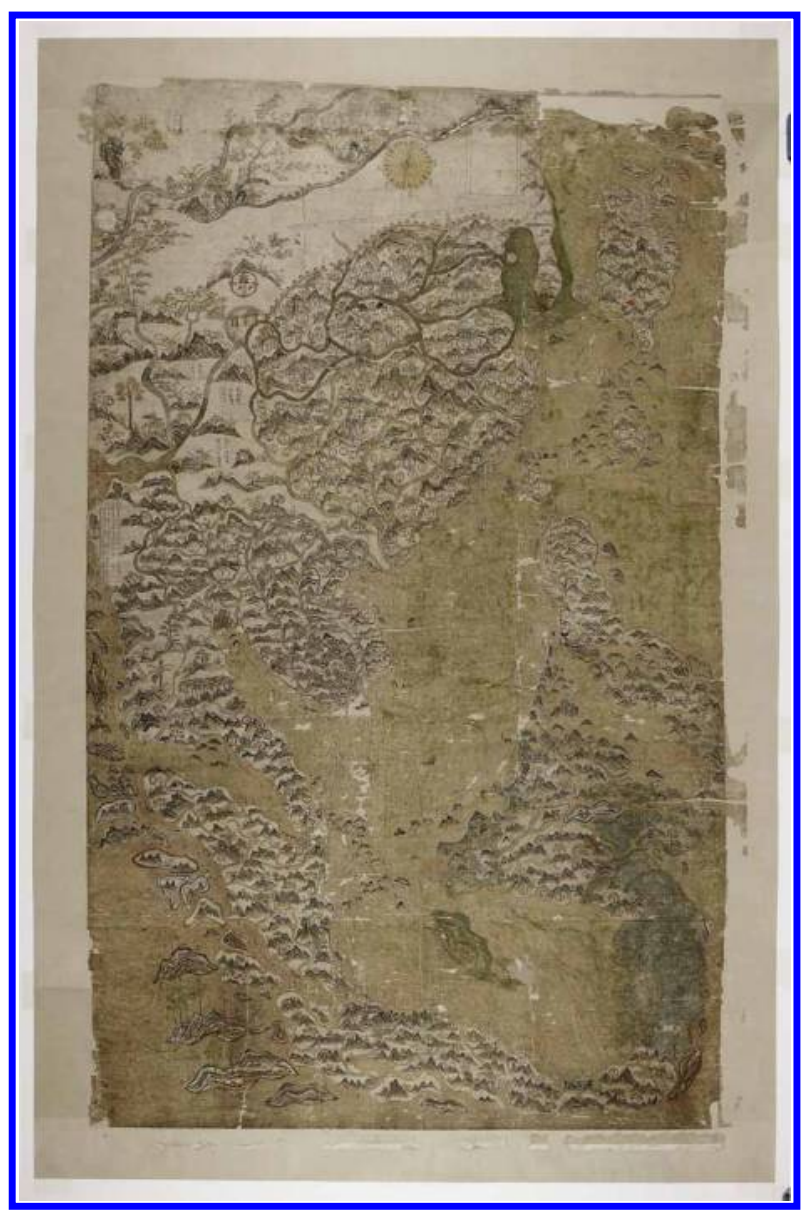

Figure 2 After conservation

圖 2 修復後的航海圖

本京都Yoshida Co., Ltd. ) 黏合劑覆貼在航海圖正 面, 使它暫時穞固下來, 接着以石州和紙 (日本東 京Masumi Corporation產品) 作為航海圖的假邊 緣, 背面朝外, 平放於日式禂板（karibari）上風 乾。待乾燥後, 再以相同的假邊緣把航海圖固定在 聚甲基丙烯酸甲酯（壓克力）板上; 然後以掃子或 透過Sympatex ${ }^{\circledR}$ 薄膜 (人造透濕物料, 購自 http: // www.conservation-by-design.co.uk) 慢慢局部將補 丁、厚紙邊及殘留的黏合劑加濕, 然後再以手術 刀、竹刮及鑷子把它們移除。我們在原位保留寫有 十七世紀註釋的早期紙邊, 並把宣紙的色調染成航 海圖的底色, 用來填補缺失處（宣紙為中國安徽的 安徽紙廠產品）, 這方法能避免航海圖變形, 並只 在有需要的部份施加最少量的濕氣, 整個修復過程 歷時多月。

我們把三層輕薄的「薄美濃紙」（日本美濃市長 谷川和紙工房產品），利用小麥澱粉製成的漿糊裱 貼在航海圖背面, 使航海圖具柔韌性, 與此同時保 留了卷軸的特徵和外觀。最後, 考慮到長遠保存的 需要, 我們決定用和紙鉸將航海圖沿着四邊貼在輕 巧的蜂窩紙板上 (圖2) 平放儲存。 
The collaborative nature of the treatment, together with the enthusiasm of scholars wishing to gain more information from our observations, made this an extraordinary experience during which important discoveries about the map were made and conservation challenges were met.

\section{References 參考文獻}

除去背䘽布的過程中, 我們對航海圖背面進行了 仔細檢查, 發現補丁交疊在一起, 並用上不同種類 的紙張 ; 在黏合劑的表面某些地方更留有1919年䚇 布花紋的印痕, 而其他地方則看到一種較粗糙的圖 紋, 或兩者皆見。這說明航海圖不僅在二十世紀以 前已有另一背褤, 而且進行該托裱的前後分別作了 兩次修補, 加上之前發現的碎布片, 充分印證明了 更早期的托裱。這些觀察結果豐富了《東西洋航海 圖》修復和裝裱的初步時序。

揭去背福布的航海圖, 同時也為前所未知的製圖 技巧提供了有力證明。我們發現航海圖背面隱藏了 一幅繪有主要航線的路線圖, 與正面所見的相符, 意外地說明了航海圖是先繪畫標有精確羅盤方位的 貿易航線網絡。這亦推動了有關該航海圖的製作方 法及出處的學術討論。

我們透過各種分析技術（包括偏光顯微鏡、拉曼 光譜、X射線熒光光譜及傅里葉轉換紅外線光譜) 來辨認航海圖紙張、補丁、裱布和顏料層的物料成 分, 幫助了解航海圖的製作方法。

這個修護計劃的合作模式, 加上學者熱切期待我 們的研究結果能提供更多資料, 讓我們在過程中從 航海圖取得許多重要的新發現, 更克服了修護上的 種種困難，造就了一次異常難忘的合作體驗。

[1] Batchelor, R. 2013. The Selden Map Rediscovered: A Chinese Map of East Asian Shipping Routes, c. 1619. Imago Mundi, 65(1): 37-63.

[2] Craster, H.H.E. 1919. Some old maps of China. Bodleian Quarterly Record, 2: 226-227.

[3] Oka, Y. 2006. Dry Backing Removal Used for Japanese Paintings. In: S. Jaques, (ed.) Edinburgh Conference Papers. Leigh, Worcester: Institute of Paper Conservation, pp. 227-230.

[4] Taguro, T. 2011. 'Dry' Method for Removing the Initial Lining. In: M. Kato and K. Yamaguchi, (eds.) 33rd International Symposium on the Conservation and Restoration of Cultural Property: Restoration of Japanese Paintings. Tokyo: National Research Institute for Cultural Properties, pp. 155-164. 